\title{
Geothermal Map of California (1:1,500,000)
}

\author{
Edited by Susan F. Hodgson and Leslie G. Youngs \\ Cartography by Roberto A. Coronel
}

The digitally produced map is created by the Division of Oil, Gas, and Geothermal Resources and the California Geological Survey, under the California Department of Conservation. These two divisions provided most of the data, but some map information is from the U.S. Geological Survey, the U.S. Bureau of Land Management, the California Energy Commission, and the Geo-Heat Center of the Oregon Institute of Technology. Price: US\$3, flat or folded, handling and shipping included.

The Geothermal Map of California is the most comprehensive geothermal map of California available and an interesting one from several points of view. One is the commercial, for more electricity from geothermal resources is generated in the United States than in any other country and most comes from California-about 2,429 megawatts of electricity in 1998 (per the California Energy Commission). (The States of Hawaii, Nevada, and Utah also generate small amounts.)

Today in 2002, about 10 percent of the electricity in Northern California and about 5 percent of the electricity in the entire state are generated from geothermal hot water and steam. The map illustrates where the electricity is generated-the locations of the geothermal fields, wells with high-temperature resources, and power plants with the plant names.

"High-temperatureî geothermal resources are defined as those with temperatures greater than $100^{\circ} \mathrm{C}$. The map calls wells used to extract these resources steam- and hot-water production wells, and plugged- and abandoned-production wells. Additional information on high-temperature geothermal wells, including injection wells and temperature-gradient holes, is available from the Division of Oil, Gas, and Geothermal Resources, which regulates the drilling, operation, and plugging and abandonment of these wells in California. Visit the division website on the Internet at <http://www.conservation.ca.gov>.

Six California counties have geothermal electrical-generation projects, which include 46 power plants, and one county has a project underway. The power plants and their names are located on the map. For further information on power plants and electrical generation from geothermal resources, visit the California Energy Commission on the Internet at <http://www.energy.ca.gov>. However, electrical generation from the very hottest geothermal resources is only one part of California's geothermal picture.

The state abounds in cooler geothermal resources, commonly called "low-temperature" and defined as thermal waters from $20^{\circ}$ to $100^{\circ} \mathrm{C}$. Many —in fact 299 - of these resources are thermal springs, which are dispersed more widely on the map than any of the other geothermal features (except perhaps some of the low-temperature commercial projects related to the thermal springs). The other geothermal features on the map-fields, wells (high- and low-temperature), and power plants-cluster together to the point that five inset maps plus a separate small map of the state are needed to illustrate them.

Data about each thermal spring are presented in a chart on the back of the map. These include the name of the spring, the latitude and longitude, the county, the highest recorded temperature in ${ }^{\circ} \mathrm{C}$, the flow rate in liters per minute, and the historical uses, such as water-supply augmentation, baths and pools, space heating, district heating, irrigation, aquaculture, greenhouse- and heat-exchanger applications, bottled water, idle or abandoned projects, and undeveloped springs.
In 1993, the California Geological Survey prepared a list of low-temperature geothermal wells in the state. These are shown on a small map of California printed alongside the larger map of the state.

Commercial low-temperature projects occur in 28 counties, and the locations of 99 of the projects are shown on the smaller map, as well. The projects, as identified by the Geo-Heat Center of the Oregon Institute of Technology, include aquaculture, district heating, greenhouses, industrial, resorts and pools, and space heating. For more about commercial, low-temperature geothermal projects in the state or a more extensive project list, contact John Lund, Director of the Geo-Heat Center at the Oregon Institute of Technology, E-mail: lundj@oit.edu. The Geo-Heat Center may be found on the Internet at $<$ http://geoheat.oit.edu $>$.

Three kinds of geothermal regulatory and resource boundaries are delineated on the map: Division of Oil, Gas, and Geothermal Resources district limits encompassing the whole state, division administrative field limits surrounding developed geothermal sites, and federal Known Geothermal Resource Areas, called KGRAs, administered by the U.S. Bureau of Land Management. KGRAs are substantially larger than the geothermal fields and some are found in places where no fields are designated. In a few cases, portions of fields extend beyond the KGRA boundaries. Some of the thermal springs and most of the high-temperature geothermal production wells are within field and KGRA boundaries, but not all.

From an artistic point of view, the attractive, bright pastels of the map; the topographical overlay on the larger drawing of the state, ranging from cream in the valleys to a darker tan in mountainous terrain; and the placement of the map legend, insets, and the two renditions of the state all help illustrate the geothermal resources story.

At a glance you can pick out the mountains and valleys, the hot springs, the wells, the low-temperature projects, and the electrical generation projects. With the same glance you can see how most of the state has no geothermal features and how a few portions seem to have them all. You can describe this to someone, of course, but the idea is understood more quickly by a picture-by looking at the Geothermal Map of California.

A related map, the Energy Map of California, drawn at a scale of 1:1,000,000, may be purchased for US\$5, flat or folded including shipping and handling. Geothermal in California, a booklet about geothermal resources and geothermal development written for students 13- to 18-years old, is available without charge.

For ordering please contact: California Department of Conservation, Division of Oil, Gas, and Geothermal Resources, 801 K Street, MS 20-20, Sacramento,

CA 95814-3530,

U.S.A.

\section{Susan F. Hodgson}

Superviser, Technical Publications

California Department of Conservation

Division of Oil, Gas, and Geothermal Resources

801 K Street, MS 20-20, Sacramento

CA 95814-3530

U.S.A. 


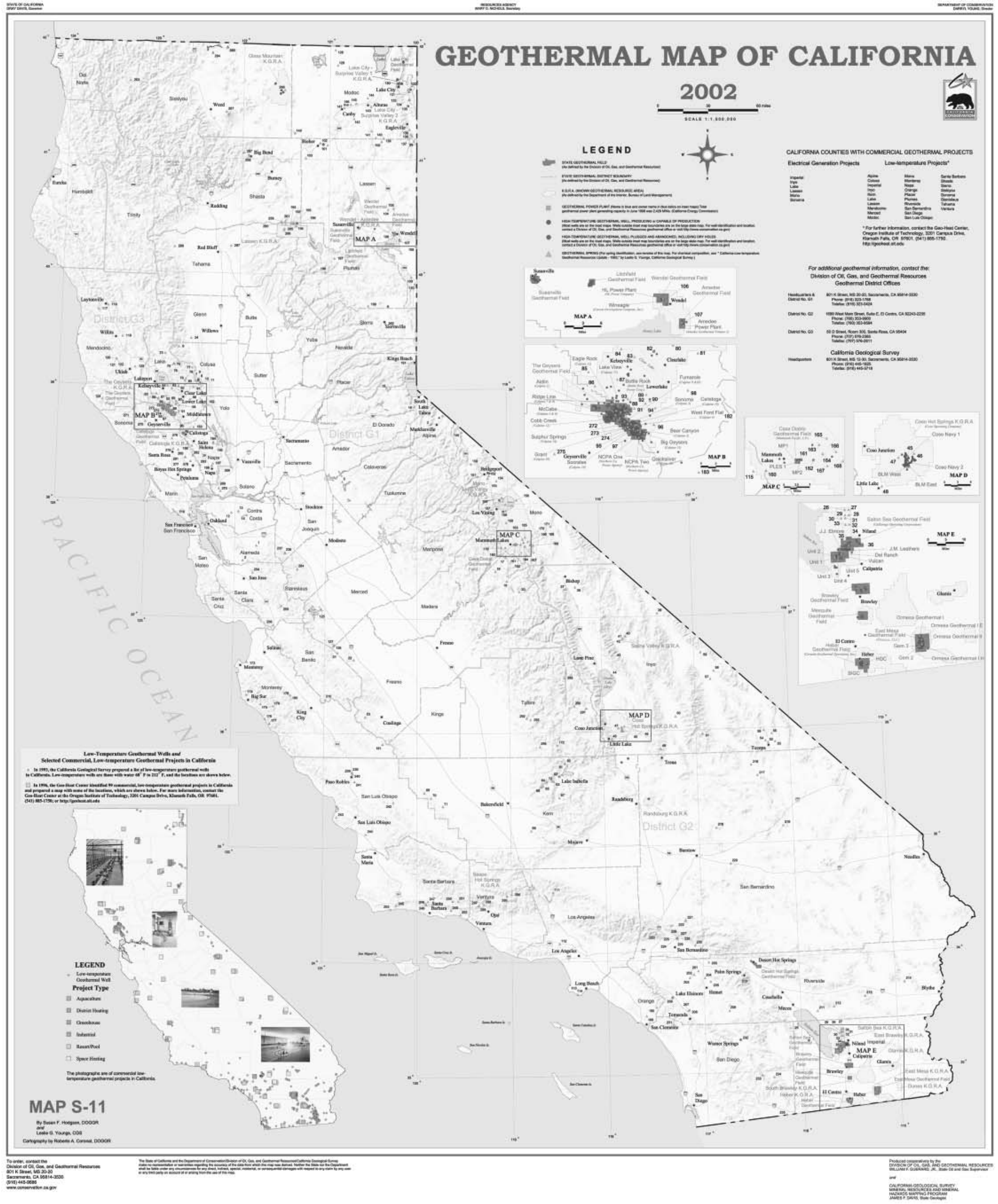

